\title{
Effect of Both Bisphenol-A and Liquorice on Some Sexual Hormones in Male Albino Rats and The Amelioration Effect of Vitamin $\mathrm{C}$ on Their Actions Eman G.E. Helal ${ }^{1}$, Mohamed A. Abdelaziz ${ }^{2}$, Abeer Zakaria ${ }^{1}$
}

${ }^{1}$ Zoology Department, Faculty of Science, Al-Azhar University (Girls), ${ }^{2}$ Physiology Department, Faculty of Medicine, Al-Azhar University.

*Corresponding Author: Eman G.E. Helal, E-mail: emanhelal@ hotmail.com, Mobile: 00201001025364, Orchid.org/0000-0003-0527-7028

\section{ABSTRACT}

Background: Xenoestrogens are defined as chemicals that mimic some structural parts of the physiological estrogen compounds, therefore may act as estrogen or could interfere with the actions of endogenous estrogens. Phytoestrogens (plant estrogens) are substances that occur naturally in plants. They have asimilar chemical structure to our own body's estrogen. Vitamin C, also known as ascorbic acid, is used to prevent and treat scurvy.

Objective: The aim of the study was to clarify the effect of both bisphenol-A (BPA) and liquorice together on some sexual hormones and illustration of the effect of vitamin $\mathrm{C}$ on their actions.

Materials and methods: Thirty male albino rats were used and divided into three groups: Group I: control (untreated group), Group II: rats treated with BPA and liquorice, Group III: rats treated with BPA and liquorice in addition to vitamin C. Blood samples were collected for different biochemical investigations.

Results: The biochemical results showed high significant increase $(\mathrm{p}<0.01)$ in the activities of ALT, AST, urea, creatinine, FSH, prolactin, total cholesterol, triglycerides, LDL-C, VLDL, LDL/HDL and TC/HDL levels. There was high significant decrease $(\mathrm{p}<0.01)$ in HDL-C, total protein, albumin, globulin, testosterone, and LH. These results turned back to the normal values after receiving the vitamin $\mathrm{C}$ as compared to normal group.

Conclusion: it could be concluded that phytoestrogen and xenoestrogen had undesirable effects and it's recommended to minimize the utilizing of these compounds to protect people from its hazardous effects.

Keywords: BPA, Liquorice, Vitamin C, Hormonal assay, Biochemical parameters.

\section{INTRODUCTION}

One of the environmental contaminants and a famous estrogenic endocrine disruptor is the bisphenol-A (BPA), which is used in the creation of polycarbonate plastic ${ }^{(1)}$ (e.g. water bottles and baby bottles) and epoxy resins (e.g. inside coating in metallic food cans) and as a non-polymer preservative to other plastics. BPA is also found in polymers used in dental materials ${ }^{(2)}$. However, recent evidence also points to that exposure to BPA may occur through dermal contact with thermal papers widely used in cash register receipts. Therefore, it becomes an included part of the food chain. The harmful effects of BPA are largely associated to its estrogenic activity. The exposure of animal to BPA elucidates multiple effects on the male and female reproductive system in various animal models. The herbs chosen for this study, contain phytoestrogens as shown from their chemical constituents. Liquorice (Glycyrrhizaglabra) a family of Leguminosae, is a plant that grows in Egypt and other countries of the world. Its roots possess some nutritional value and medicinal properties. It is widely used as a cold drink and in the preparation of some pharmaceuticals such as hematinic pills (3). Phytochemical analysis of liquorice (Glycyrrhizaglabra) root extract showed that it contains triterpenes saponin (glycyrrhizin, glycyrrhetinic acid and liquirtic acid), flavonoids (liquiritin, isoflavonoids and formononetin) and other constituents such as coumarins, sugars, amino acids, tannins, starch, choline, phytosterols and bitter principles, which are most likely responsible for its therapeutic properties. There are many phenols present in liquorice extracts such as liquiritigenin, liquiritin, isoliquiritigenin, isoliquiritin, glabridin and formononetin, which are responsible for the plant estrogen activity ${ }^{(4)}$. Medicinally its root is used widely either as tincture or fluid extract or ingredient in over the counter pharmaceutical products for cough, expectorant, asthma, peptic ulcers and hepaticprotective products. This is because of its antiinflammatory, anti-ulcerative demulcent, antimicrobial and hepatic-protective activities ${ }^{(5)}$.

Ascorbic acid (AA) or vitamin $\mathrm{C}$ is a water soluble vitamin. Ascorbic acid is a six-carbon keto-lactone, synthesized from glucose via several intermediates. It is an anti-oxidant vitamin ${ }^{(6)}$, with biological actions of particular relevance to reproduction. In humans its deficiency has been associated with a wide spectrum of clinical manifestations such as scurvy, which is a lethal condition unless appropriately treated. The antioxidant role of AA in maintaining motor abilities has been well documented. It has been shown that AA elicits its antioxidant effect through donation of electrons and protection of other compounds from oxidation. In this process, vitamin $\mathrm{C}$ itself is oxidized but unreactive and therefore ascorbic acid has been described as a good free radical scavenger. Several studies in human have demonstrated the effects of vitamin C on intestinal iron absorption, reduction of harmful oxidants in the stomach and vascular responsiveness. These effects have been reported to be mediated by the antioxidant actions of vitamin $\mathrm{C}$, which may play a role in iron absorption, gastric cancer prevention, vascular disease and hypertension. Vitamin $\mathrm{C}$ appears to have beneficial 161 
effects on erectile and testicular functions in healthy and unhealthy subjects with reproductive problems ${ }^{(7)}$.

\section{AIM OF THE STUDY}

This study was conducted to clarify the effect of both BPA and liquorice together on some sexual hormones and illustration of the effect of vitamin $\mathrm{C}$ on their actions.

\section{MATERIALS AND METHODS}

30 male albino rats of local strain weighting 110$130 \mathrm{~g}$ were used throughout the experiments. The animals were housed in isolated animal metal cages in a conditioned room in the animal lab of the Physiology Department, Faculty of Science, Al-Azhar University.

\section{Ethical approval:}

Approval of the Ethical Committee was obtained. This study was conducted in accordance with ethical procedures and policies approved by Animal Care and Use Committee of Faculty of science, Al-Azhar University, Cairo, Egypt. Animals were treated according to guidelines for the use and care of laboratory animal in temperature, ventilation, humidity and normal dark / light cycle with free access to water and fed on rodent chow diet all over the period of the work (4 weeks)

\section{Experimental design:}

In current study, 30 male albino rats were divided into three equal groups (10 rats in each group) as the following:

- Group I: (control group) comprised of normal rats and maintained on standard rodent chow diet and tap water ad libitum for 30 days.

- Group II: rats received orally liquorice (250 $\mathrm{mg} / \mathrm{kg}$ body weight) and BPA ( $20 \mathrm{mg} / \mathrm{kg}$ body weight for 30 days.

- Group III: rats treated with BPA and liquorice in addition to vitamin $\mathrm{C}(7 \mathrm{mg} / \mathrm{kg}$ body weight).

Body weight measurement: Body weight was recorded before and after the experiment.

\section{Blood sample collection:}

At the end of the experimental period, the blood samples were collected from the retro-orbital sinus after anesthetizing the rat by ether. Serum was separated by centrifugation at $3000 \mathrm{rpm}$ for 15 minutes at room temperature to estimate biochemical parameters.
Biochemical analysis:

Assessment of biochemical parameters:

In the present study total protein (TP), albumin concentration were estimated, then serum globulin concentrations were calculated according to the formula: $(\mathrm{g} / \mathrm{dl})$.

Globulin $(\mathrm{g} / \mathrm{dl})=$ total protein $(\mathrm{g} / \mathrm{dl})-$ albumin

The ratio of serum albumin/globulin was determined.

Aspartate aminotransferase (ASAT) and alanine aminotransferase (ALAT) activities, creatinine, Urea concentrations as well as lipid profile [cholesterol, triglycerides and high-density lipoprotein cholesterol (HDL-C)] were also determined. All parameters were estimated using Bio Merieux SA kits, France. However, ratios of TC/HDL (risk factor 1) and LDL/HDL (risk factor 2) were also calculated after calculation of serum LDL-C (low-density lipoprotein cholesterol) and VLDL (very low density lipoprotein cholesterol) using the Friedwald's ${ }^{(8)}$ and Norbert ${ }^{(9)}$ formulas, respectively as following.

Friedwald's equation: LDL $(\mathrm{mg} / \mathrm{dl})=\mathrm{TC}-\{\mathrm{HDL}+$ $[\mathrm{TG} / 5]\}$. Norbert equation: VLDL $=\mathrm{TG} / 5$.

\section{Hormonal assay:}

Estimation of serum luteinizing hormone (LH) follicles-stimulating hormone (FSH) Prolactin (P) and testosterone (T) levels were determine by using kit manufacturer instructions. All kits used for hormone assay were obtained from (Monobind Inc. lake forest CA 92630, USA).

\section{Statistical analysis}

Recorded data were analyzed using the statistical package for social sciences, version 20.0 (SPSS Inc., Chicago, Illinois, USA). Quantitative data were expressed as mean \pm standard deviation (SD). Qualitative data were expressed as frequency and percentage.

\section{The following tests were done:}

$\square \square$ Independent-samples t-test of significance was used when comparing between two means.

Chi-square (x2) test of significance was used in order to compare proportions between two qualitative parameters.

$\checkmark$ The confidence interval was set to $95 \%$ and the margin of error accepted was set to $5 \%$. The p-value was considered significant as the following:

Probability (P-value)

- P-value $<0.05$ was considered significant.

- P-value $<0.001$ was considered as highly significant.

- P-value > 0.05 was considered insignificant. 


\section{RESULT}

Results of the present study regarding the body weight are in Table 1.

Table (1): Change of body weight in the control and treated groups

\begin{tabular}{|c|c|c|c|}
\hline Parameter & $\begin{array}{c}\text { Control } \\
\text { (mean } \pm \mathrm{SEM}) \\
\mathrm{N}=10\end{array}$ & $\begin{array}{c}\text { Mixture } \\
\text { (mean } \pm \text { SEM) } \\
\mathrm{N}=10\end{array}$ & $\begin{array}{c}\text { Mixture and vitamin C } \\
(\text { mean } \pm \text { SEM }) \\
N=10\end{array}$ \\
\hline$\%$ of body weight change & $13.2 \pm 0.04$ & \begin{tabular}{|l}
$21.4 \pm 2.9 *$ \\
$8.1 \%$
\end{tabular} & \begin{tabular}{|r|}
$118 \pm 1.08$ \\
$4.0 \%$ \\
\end{tabular} \\
\hline
\end{tabular}

$\mathrm{P}^{*}<0.005$ as compared to control group.

Protein profile: (Table 2)

Table (2): Change in protein profile in the control and treated groups

\begin{tabular}{|c|c|c|c|}
\hline $\begin{array}{l}\text { Groups } \\
\text { Parameters } \\
\end{array}$ & $\begin{array}{l}\text { Control } \\
\text { (mean } \pm \text { SEM) } \\
\mathrm{N}=10\end{array}$ & $\begin{array}{l}\text { Mixture } \\
\text { (mean } \pm \text { SEM) } \\
\mathrm{N}=10\end{array}$ & $\begin{array}{c}\text { Mixture and vitamin C } \\
\text { (mean } \pm \text { SEM) } \\
\mathrm{N}=10\end{array}$ \\
\hline $\begin{array}{c}\text { Total protein }(\mathrm{g} / \mathrm{dl}) \% \\
\text { change }\end{array}$ & $6.18 \pm 0.09$ & $\begin{array}{l}4 \pm 0.10 * * \\
-37.3 \%\end{array}$ & $\begin{array}{l}4.94 \pm 0.1 \\
-17.8 \%\end{array}$ \\
\hline $\begin{array}{l}\text { Albumin }(\mathrm{g} / \mathrm{dl}) \\
\% \text { change }\end{array}$ & $3.44 \pm 0,02$ & $\begin{array}{l}1.95 \pm 0.07 * * \\
-46.9 \%\end{array}$ & $\begin{array}{l}2.48 \pm 0.06 \\
-27.9 \%\end{array}$ \\
\hline \begin{tabular}{|l|}
$\begin{array}{l}\text { Globulin }(\mathrm{g} / \mathrm{dl}) \\
\text { \% change }\end{array}$ \\
\end{tabular} & $2.78 \pm 0.24$ & $\begin{array}{l}2.1 \pm 0.1 * \\
-24.5 \% \\
\end{array}$ & $\begin{array}{l}2.46 \pm 0.15 \\
-11.5 \% \\
\end{array}$ \\
\hline $\begin{array}{l}\text { Albumin/ Globulin } \\
\% \text { change }\end{array}$ & $1.30 \pm 0.21$ & $\begin{array}{l}0.90 \pm 0.03 \\
-32.8 \%\end{array}$ & $\begin{array}{l}1.034 \pm 0.07 \\
-20.5 \%\end{array}$ \\
\hline
\end{tabular}

$\mathrm{P}^{*}<0.005, \mathrm{p}^{* *}<0.001$ as compared to control group.

Liver functions are shown in Table 3.

Table (3): Change in liver function test in the control and treated groups

\begin{tabular}{|c|l|l|l|}
\hline $\begin{array}{c}\text { Groups } \\
\text { arameters }\end{array}$ & $\begin{array}{l}\text { Control } \\
\text { (mean } \pm \text { SEM) N=10 }\end{array}$ & $\begin{array}{l}\text { Mixture } \\
\text { (mean } \pm \text { SEM) N=10 }\end{array}$ & $\begin{array}{c}\text { Mixture and vitamin C } \\
\text { (mean } \pm \text { SEM) N=10 }\end{array}$ \\
\hline ALT (U/dl) & $19.8 \pm 2.3$ & $2.7 \pm 0.75^{* *}$ & $29.1 \pm 0.005$ \\
$\%$ change & & $40.3 \%$ & $15.9 \%$ \\
\hline AST (U/dl) & $23.4 \pm 3.1$ & $0.0 \pm 0.52^{* *}$ & $33.0 \pm 0.06$ \\
$\%$ change & & $69.5 \%$ & $41.5 \%$ \\
\hline
\end{tabular}

$\mathrm{p}^{* *}<0.001$ as compared to control group

Lipid profile: (Table 4).

Table (4): Changes in lipid profile in the control and treated groups

\begin{tabular}{|l|l|l|l|}
\hline $\begin{array}{c}\text { Groups } \\
\text { Parameters }\end{array}$ & $\begin{array}{c}\text { Control } \\
\text { (mean } \pm \text { SEM) N=10 }\end{array}$ & $\begin{array}{l}\text { Mixture } \\
\text { (mean } \pm \text { SEM) N=10 }\end{array}$ & $\begin{array}{c}\text { Mixture and vitamin C } \\
\text { (mean } \pm \text { SEM) N=10 }\end{array}$ \\
\hline T-C (mg/dl) & $142 \pm \mathbf{2 . 2}$ & $172.6 \pm \mathbf{0 . 0 6} * *$ & $149 \pm \mathbf{0 . 7 1}$ \\
\% change & & $\mathbf{2 1 . 8 \%}$ & $\mathbf{4 . 9 3 \%}$ \\
\hline T-G (mg/dl) & $82 \pm 2.6$ & $100.2 \pm 0.17^{* *}$ & $88 \pm 0.7$ \\
\% change & & $22.6 \%$ & $7.32 \%$ \\
\hline HDL-C (mg/dl) & $56 \pm 1.7$ & $38.31 \pm 0.9^{* *}$ & $43 \pm 0.005$ \\
\% change & & $-31.0 \%$ & $-23.2 \%$ \\
\hline LDL-C & $70.6 \pm 1.8$ & $113.4 \pm 0.13^{* *}$ & $88.4 \pm 0.14$ \\
\% change & & $61.2 \%$ & $25.21 \%$ \\
\hline VDL-C & $16.4 \pm 0.5$ & $20.02 \pm 0.04^{* *}$ & $17.6 \pm 0.31$ \\
\% change & & $25.7 \%$ & $7.32 \%$ \\
\hline LDL/HDL & $1.27 \pm 0.04$ & $3.0 \pm 0.06^{* *}$ & $2.05 \pm 0.04$ \\
\% change & & $136.6 \%$ & $61.42 \%$ \\
\hline TC/HDL & $2.56 \pm 2.4$ & $4.62 \pm 0.07 * *$ & $3.47 \pm 0.03$ \\
\% change & & $76.94 \%$ & $35.6 \%$ \\
\hline
\end{tabular}

$\mathrm{P}^{* *}<0.001$ as compared to control group 
Kidney functions: The data are in table (5).

Table (5): change in kidney function tests in the control and treated groups

\begin{tabular}{|c|l|l|l|} 
Groups & $\begin{array}{c}\text { Control } \\
(\text { mean } \pm \text { SEM }) \\
\mathrm{N}=10\end{array}$ & $\begin{array}{c}\text { Mixture } \\
(\text { mean } \pm \text { SEM }) \\
\mathrm{N}=10\end{array}$ & $\begin{array}{l}\text { Mixture and vitamin } \\
(\text { mean } \pm \text { SEM) } \\
\mathrm{N}=10\end{array}$ \\
\hline $\begin{array}{c}\text { Urea }(\mathrm{mg} / \mathbf{d l}) \% \\
\text { change }\end{array}$ & $40.2 \pm 0.9$ & $66.7 \pm 1.3 * *$ & $53.7 \pm 0.7$ \\
Creatinine(mg/dl) $\%$ & $0.5 \pm 0.2$ & $62.9 \%$ & $34.4 \%$ \\
change & & $0.72 \pm 0.07 * *$ & $0.58 \pm 0.04$ \\
\end{tabular}

$\mathrm{P}^{* *}<0.001$ as compared to control group

Hormones: (Table 6).

Table (6): changes in hormonal profile in the control and treated groups.

\begin{tabular}{|c|c|c|c|}
\hline $\begin{array}{l}\text { Groups } \\
\text { Parameters }\end{array}$ & $\begin{array}{c}\text { Control } \\
(\text { mean } \pm \text { SEM }) \mathrm{N}=10\end{array}$ & $\begin{array}{c}\text { Mixture } \\
(\text { mean } \pm \text { SEM }) \mathrm{N}=10\end{array}$ & $\begin{array}{l}\text { Mixture and vitamin } \\
\mathrm{C}(\text { mean } \pm \text { SEM }) \mathrm{N}=10\end{array}$ \\
\hline $\begin{array}{l}\text { Prolactin(ng/ml)\% } \\
\text { change }\end{array}$ & $4.3 \pm 0.07$ & $\begin{array}{c}\mathbf{6 . 7 1} \pm 0.07 * * \\
55 \%\end{array}$ & $\begin{array}{l}4.91 \pm 0.06 \\
15.1 \%\end{array}$ \\
\hline $\begin{array}{c}\text { Testosterone }(\mathrm{ng} / \mathrm{ml}) \\
\% \text { change }\end{array}$ & $16.2 \pm 0.6$ & $\begin{array}{l}9.4 \pm 0.16 * * \\
-39.5 \% \\
\end{array}$ & $\begin{array}{l}13.7 \pm 0.08 \\
-14.7 \%\end{array}$ \\
\hline $\begin{array}{c}\text { FSH }(\mathrm{mlu} / \mathbf{m l}) \\
\% \text { change }\end{array}$ & $2.7 \pm 0.07$ & $\begin{array}{c}5.22 \pm 0.95^{* *} \\
92.6 \% \\
\end{array}$ & $\begin{array}{l}3.77 \pm 0.02 \\
45.1 \%\end{array}$ \\
\hline $\begin{array}{c}\mathbf{L H}(\mathrm{mlu} / \mathbf{m l}) \\
\% \text { change }\end{array}$ & $10.7 \pm 0.5$ & $\begin{array}{c}7.51 \pm 0.07 * * \\
-25.5 \% \\
\end{array}$ & $\begin{array}{l}9.0 \pm 0.1 \\
-15.1 \% \\
\end{array}$ \\
\hline
\end{tabular}

$\mathrm{P}^{*}<0.005, \mathrm{P}^{* *}<0.001$ as compared to control group.

\section{DISCUSSION}

\section{Body weight:}

The findings in this study showed an increase in body weight in mixture experimental group. This effect may be attributed to the Glycyrrhizaglabra. Increase in body weight by Glycyrrhizaglabra root extract is in accordance with that reported by Miller ${ }^{(10)}$ who demonstrated that Glycyrrhizaglabra inhibits $11 \beta$ hydroxysteroid dehydrogenase and induces excess release of mineralocorticoids, which cause retention of sodium and water that leads to edema and increase in body weight. However, the increased body weight is explained by the improvement in feeding efficiency.

\section{Liver function:}

In the present study there was an increase in activities of ALT and AST in mixture group. BPA has adverse effects on the liver, as indicated by increased activities of ALT and AST enzymes. Elevated levels of serum enzymes ALT and AST are indicators of cellular leakage and loss of functional integrity of the cell membrane in the liver. The liver is a target tissue for endocrine-disrupting chemicals. Specific estrogen receptors exist in the liver and cellular responses involving estrogen interactions have been identified. BPA has adverse effects on the liver, as indicated by increased activities of ALT and AST enzymes (11). Bisphenol A is reported to increase the hepatic oxidative stress and mitochondrial dysfunction ${ }^{(12)}$. Also liquorice has toxic effect on the liver after $G$. glabra administration. It causes changes in hepatocyte tissue, congestion and necrosis of hepatocytes in the liver of extract-treated animals which caused by metabolism of plant extract in theliver. Also, glycyrrhizin and coumarins, are two active gradients of liquorice, which have toxic effect in the liver causing hepatic conjugation or hemorrhage ${ }^{(13)}$. When the animals were treated by vitamin C, elevation of ASAT and ALAT was reduced to a value close to the normal. This may be due to the antioxidant activity of vitamin C. This protective effect of vitamin $\mathrm{C}$ against toxicity of the mixture groups occurred because of its antioxidant action ${ }^{(14)}$. A previous study suggested that the ameliorating effects of vitamin $\mathrm{C}$ may be likely mediated via inhibition of free radicals generation and/or increasing free radical scavenging activity.

\section{Protein profile:}

The present work results showed changes in protein profile in the mixture-treated rats. The physiological and biochemical activities in the albino rats were completely disturbed after the oral administration of mixture. In the present study, mixture-treated group showed, decreased protein content when compared to the control. Decreased levels of serum protein might be due to deactivation of protein disulfide isomerase, a multifunctional protein critically involved in the folding and shedding of cellular proteins ${ }^{(15)}$. The decreased protein levels could be related to damage of cells caused by BPA. The decrease in protein content 
under stress induced by BPA may be attributed to the utilization of amino acids in various catabolic reactions. BPA may either act by activating or inhibiting enzyme activities in the cell or destruction of the cell organelles with liberation of particular enzymes is one of the reasons to alter the expression of total proteins. Another reason is oxidative stress influenced by excess reactive oxygen species (ROS) produced in serum that are known to damage proteins (16). The depletion of total protein content observed in this investigation can be correlated to this fact. BPAinduced oxidative stress in serum are known to damage proteins ${ }^{(17)}$. This can lead to various diseases, including cancer, infertility and neurodegenerative diseases. There is much concern that exposure to BPA causes endocrine toxicity in man and wild life. Also, liquorice has toxic effect. It is possible that the chemical constituents of the plant parts of liquorice, majorly the alkaloids, are responsible for protein depletion as a result of increased protein catabolism and increase excretion in urine ${ }^{(18)}$. Liquorice is an extract from the Glycyrrhizaglabra plant, which contains glycyrrhizic acid, or GZA. GZA is made of one molecule of glycyrrhetinic acid and two molecules of glucuronic acid. When administered orally, the product of glycyrrhetic acid is found in urine.

Additionally, vitamin $\mathrm{C}$ resulted in a significant improvement in the serum total protein level. Vitamin has the ability to prevent oxidative stress, which affects the liver that is the main site for protein synthesis in the body ${ }^{\left({ }^{19}\right)}$. This may be due to the antioxidant activity of vitamin $\mathrm{C}$ that exhibited a hepato-protective effect against liver damage.

\section{Lipid profile:}

In the present study, there was a significant increase in all the parameters of lipid profile, except HDL which recorded a significant decrease in mixture group and nonsignificant change in vitamin $\mathrm{C}$ group when compared to control group. Exposure to low doses of the mixture increases the insulin expression and production by the pancreas ${ }^{(\mathbf{2 0})}$. Insulin is known to increase genesis by both post-translational protein modifications and transcriptional mechanisms. It was found that activity of sterol regulatory element binding protein 1c (SREBP-1c), which regulates cholesterol metabolism, were activated by increased insulin level. So, insulin is likely to contribute to hypercholesterolemia following BPA treatment. However, this did not rule out the contribution of other mechanisms independent of insulin and possibly involving direct effects of BPA on the liver, to the hepatic transcriptional impacts detected in treated mice (21).

BPA caused hyperlipidemia that is an important agent for cardiovascular, atherosclerosis disease, myocardial infarction and cerebrovascular disease. Mechanistically, liquorice or environmental BPA acts on estrogen receptors and do estrogen action. Both BPA (xenoestorgen) and liquorice (phytoestrogen) are a well-known endocrine-disrupting chemical that bind to the estrogen receptors (ER alpha and ER beta) and disrupting the lipid profile ${ }^{(22)}$.

Meanwhile, after treating by vitamin $\mathrm{C}$, a watersoluble antioxidant, which is an important factor in lipid regulation, there was an increase in HDL levels and protection against LDL oxidation ${ }^{(23)}$.

\section{Kidney function:}

This study also demonstrated that treatment of rats in the mixture group induced a highly significant increase in serum urea and creatinine. BPA can cause injury in the kidney, and other organs by forming reactive oxygen species (ROS) that may be due to the oxidative stress induced by BPA on the rats kidney tissues as investigated by Korkmaz et al. (24). Oxidative stress can lead to chronic inflammation, which in turn could mediate most chronic diseases. The toxicity of liquorice extract showed toxic changes in the kidney after G. glabra administration. An increase in intake of liquorice can cause many toxic effects. Hyper-mineralocorticosteroid syndrome can occur when the body retains sodium, loses potassium altering biochemical and hormonal activities. Many adverse effects of liquorice poisoning can be seen and most are attributed to the mineralocorticoid effects of GZA. People with previously existing kidney problems may be more susceptible to GZA and liquorice poisoning (25). However, treatment with vitamin $\mathrm{C}$ resulted in a significant improvement in serum levels of biochemical parameters of the kidneys. Tawfik and Al-Badr ${ }^{(26)}$ recorded that dietary antioxidants such as vitamin $\mathrm{C}$ had a modulator effects on mixture groupinduced serum urea due to oxidative damage of the kidneys of rats.

\section{Hormone:}

In the present study, the mixture of bisphenol A and liquorice caused hormonal disturbances, where it showed a significant increase in FSH and prolactin and significant decrease in $\mathrm{LH}$ and testosterone hormone levels. As revealed from the data obtained, BPA administration caused hyperprolactinemia. Similar data were obtained by Rosmary $\boldsymbol{e t}$ al. ${ }^{(27)}$ who stated that BPA has estrogen-like effect mimicked estradiol in inducing hyperprolactinemia in rats. They revealed that BPA may alter estrogen receptor and/or estrogenresponsive genes that affect the lactotrophs in rats. However, Funabashi et al. ${ }^{(28)}$ suggested that BPA could have hypothalamic actions and induce changes in neural systems that could impact upon gonadotrophin secretion.

Similarly, the present study reported that BPA induced a significant elevation in FSH with concomitant reduction in LH levels. The decreases in LH observed in this study is consistent with estrogeninduced alterations observed by others. This is in 
agreement with the results of Akingbemi et al. ${ }^{(29)}$ where they reported that BPA has adverse effects on testicular function by decreasing pituitary LH secretion and reducing Leydig cells steroidogenesis. Decreased Leydig cells was compared with the decreased serum $\mathrm{LH}$ and testosterone (T) levels as well as Leydig cell androgen biosynthetic capacity. So, BPA suppressed T production via decreased $\mathrm{LH}$ secretion. There is also evidence that BPA interferes with LH receptor-legend binding. Different doses of BPA caused inhibition in spermatogenesis and seminiferous tubule in male. BPA caused a decrease in sperm count and motility and also affected sperm morphology of adult male rats. BPA has been associated with declined semen quality and increased sperm DNA damage. This also supports the toxicity of BPA on germ cell. Nakamura et al. ${ }^{(30)}$ stated that BPA, dose dependently, decreased the expressions of steroidogenic acute regulatory (StAR) protein and steroidogenic enzymes like cholesterol side chain cleaving enzyme P450scc (CYP11A1), P45017, and 17-HSD mRNA. Therefore, the decreased expression of steroidogenic enzymes and StAR protein concerned in testosterone synthesis might be primarily related to the decreased testosterone levels as a result of BPA treatment. Gurmeet et al. ${ }^{(31)}$ supposed that the decreased testosterone level may be the cause of alteration of spermatogenesis and disturbance of the seminiferous epithelium. Additionally, the disturbances in hypothalamic-pituitary-gonadal axis and decrease in Sertoli cell phagocytic function might be induced by BPA administration. The cytotoxic agents can affect the spermatogenic cells due to their high mitotic activity. The results are in accordance with Vandenberg et al. (32). They showed morphological damages in testis after administration of BPA and provided the evidence for their toxicity on the male reproductive system. It has been reported that liquorice reduced serum testosterone level and affected androgen metabolism by inhibiting the enzyme $\beta-6$ HSD, and $17 \beta \mathrm{HSD}$ hydroxysteroid dehydrogenase or by stimulating aromatase. Therefore, it was proposed that liquorice could cause the deficiency of serum testosterone, leading to sexual dysfunction or decline of libido in men ${ }^{(33)}$.

Tamer et al. ${ }^{(34)}$ and Helal et al. ${ }^{(35)}$ demonstrated that liquorice affects the adrenal cortex by stimulating glucocorticoids production, which affects the reproductive hormones. Small amounts of testosterone are secreted by the adrenal glands and estradiol is also secreted to a lesser degree by the adrenal glands. The effect of liquorice on serum testosterone among healthy women was found to decrease testosterone because of the inhibition of 17-hydroxysteroid dehydrogenase. This finding indicates that liquorice may be beneficial in treating women with hirsutism and polycystic ovary syndrome. Liquorice also supports the adrenal gland in stimulating excretion of hormones from the adrenal cortex and in promoting estrogenic activity. Therefore, it was proposed that liquorice causes the deficiency in serum testosterone. Glabridin, the major isoflavone in liquorice and many other phenols such as liquiritigenin, liquiritin, isoliquiritigenin, isoliquiritin, glabridin and formononetin are responsible for phytoestrogen activity and estrogenic properties, which cause hormonal disturbance and decrease in sperm count ${ }^{(36)}$. Meanwhile, vitamin $\mathrm{C}$ recorded a significant improvement in the value of testosterone hormone and elevated its level as compared to the mixture-treated animals. Biswas et al. ${ }^{(37)}$ reported that ascorbic acid stimulate testicular steroid dehydrogenase activity and increase plasma testosterone level. Karanth $\boldsymbol{e t}$ al. ${ }^{(38)}$ reported that ascorbic acid is a vitaminergic transmitter that activates the release of both FSH and LH from the anterior pituitary gland by autocrine action by means of nitric oxide. Then, LH causes the release of testosterone from Leydig cells.

\section{CONCLUSION}

It could be concluded that phytoestrogen and xenoeostrogen have undesirable effects and it is recommended to minimize the utilizing of these compounds to protect people from its hazardous effects.

\section{REFERENCE}

1- Chitra K C, Latchoumycandane C, Mathur P (2002): Effect of nonylphenolon the antioxidant system in epididymal sperm of rats. Archives of Toxicology, 76: 545-551.

2- Chapin R E, Adams J, Boekelheide K et al. (2008): NTPCERHR expert panel report on the reproductive anddevelopmental toxicity of bisphenol a. Birth Defects Research. Part B, Developmental and Reproductive Toxicology, 83: 157-395.

3- Fenwick G, Lutomski J, Nieman C (1990): Glycyrrhizaglabra L. (Liquorice): Composition, uses and analysis. Food Chem., 38 (2): 119-143.

4- Arystanova T, Irismetov M, Sophekova A (2001): Chromatographic determination of glycyrrhizinic acid in Glycyrrhizaglabrapreparation. Chem Nat Com., 37: 89-91

5- Tang $Z$ L, Tong $Y$, Chen $X$ et al. (2015): A systematic review of the anticancer properties of compounds isolated from licorice (Gancao). Planta Med., 18: 1670-1687.

6- Padayatty S J, Katz A, Wang Y et al. (2003): Ascorbic acid as an antioxidant: evaluation of its role in diseaseprevention. Journal of the American College of Nutrition, 22 (1): 18-35.

7- Kehinde O S, Christianah O I, Oyetunji O A (2018): Ascorbic acid and sodium benzoate synergistically aggravates testicular dysfunction in adult Wistar rats. International Journal of Physiology, Pathophysiology and Pharmacology, 10 (1): 39-46.

8- Friedwald's W T, Levy R I, Fredrickson D S et al. (1999): Estimation of the concentration of low-density lipoprotein cholesterol in plasma, without use of the preparative ultracentrifuge. Clin. Chem., 18: 499-502.

9- Norbert WT (1995): clinical guide to laboratory tested.3rd ed. saunders W.B. company, Philadelphia. 
https://onlinelibrary.wiley.com/doi/abs/10.1111/j.1537-

2995.1995.tb03571.x

10- Miller I (1998): Herbal medicine: Selected clinical considerations focusing on known or potential drug-herb interaction. Arch. Inter Med., 158: 2200-2211.

11- Henderson A R, Moss D W (2005): Tietz fundamentals of clinical chemistry. In: Burtis, C.A. Ashwood, E.R. (Eds.), Enzymes. Lubbok, Texas, Pp: 352-390.

12- Eshak M G, Osman H F (2014): Biological Effects of Chitosan against Bisphenol A Induced Endocrine Toxicity and Androgen Receptor Gene Expression Changes in Male Rats. Int J pharmaceutical Clin Res., 6 (4): 300-311.

13- Stansbury J (2016): Medical Clinic Apothecary Natural Goods. http:// www. battlegroundhealingarts.com/articles/the apiaceaefamilymedicinal-plant-research-summary/.

14- Dosuky M A, Zaghlol D A, Ouies S M et al. (2018): Effects of Monosodium Glutamate on the Liver of Male Adult Albino Rat and the Possible Protective Role of Vitamin C (Light and Electron Microscopic Study). Med. J. Cairo Univ., 86 (7): 3407-3418.

15- Hiroi T, Okada K, Imaoka $S$ et al. (2006): Bisphenol A binds to protein disulfide isomerase and inhibits its enzymatic and hormone binding activities. Endocrinology, 147 (6): $2773-80$.

16- Zhang X, Chen C H, Confino E, Barnes R et al. (2006): Increased endometrial thickness is associated with improved treatment outcome for selected patients undergoing in vitro fertilization embryo transfer. Fertility and Sterility, 83: 336-3.

17- Kabuto H, Amaklawa M, Shishibori T (2004): Exposure to Bisphenol-A dying embryonic fetal life and reactive oxygen species in mouse tissues. Environ. Res., 93: 31-35.

18- Armanini D, Fiore C, Mattarello M J et al. (2002): "History of the endocrine effects of licorice". Experimental and Clinical Endocrinology \& Diabetes, 110 (6): 257-61.

19- Barja G, Lopez T M, Perez-Campo R et al. (1994): Dietary vitamin $\mathrm{C}$ decreases endogenous protein oxidative damage, malondialdehyde, and lipid peroxidation and maintains fatty acid unsaturation in the guinea pig liver. Free Radicals Biology and Medicine, 17(2):105-15.

20-Nadal A, Alonso-Magdalena P, Soriano S et al. (2009): The pancreatic beta-cell as a target of estrogens and xenoestrogens: implications for blood glucose homeostasis and diabetes. Mol Cell Endocrinol., 304: 63-68.

21- Marmugi A, Ducheix S, Lasserre F et al. (2012): Low doses of bisphenol A induce gene expression related to lipid synthesis and trigger triglyceride accumulation in adult mouse liver. Hepatology, 55: 395-407.

22- Hassan H, Serag H, Abdel-Hamid N, Amr M (2015): Synergistic curative effect of chicory extract and cisplatin against thioacetamide-induced hepatocellular carcinoma. Hepatoma Res., 1: 147-54.

23- El Mashad G M, ElSayed H M, Nosair N A et al. (2016): Effect of vitamin $\mathrm{C}$ supplementation on lipid profile, serum uric acid, and ascorbic acid in children on hemodialysis. Saudi Journal of Kidney Diseases and Transplantation, 27 (6): 1148-1154.

24- Korkmaz A, Aydoğan M, Kolankaya D et al. (2011): Vitamin C coadministration augments bisphenol A, nonylphenol, and octylphenol-induced oxidative damage on kidney of rats. Environmental Toxicology, 26 (4): 325337.

25- Omar H R, Komarova I, El-Ghonemi M A et al. (2012): Licorice abuse: time to send a warning message. Therapeutic Advances in Endocrinology and Metabolism, 3 (4): 125-138.

26. Tawfik M S, Al-Badr N (2012): Adverse effects of monosodium glutamate on liver and kidney functions in adult rats and potential protective effect of vitamins $\mathrm{C}$ and E. Food and Nutrition Sciences, 3 (5): 651-659 .

27- Rosmary S, Nancy G et al. (1997): The environmental estrogen Bisphenol-A stimulates prolactin release in vivo and in vitro. Endocrinology, 138: 1780-1786.

28- Funabashi T, Sano A, Mitsushima D et al. (2003): Bisphenol-A increases progesterone receptor immunoreactivity in the hypothalamus in a dose dependent manner and affects sexual behavior in adult ovaricectomised rats. J. Neuroendocrinol., 15: 134-140.

29- Akingbemi BT, Ge R, Rosenfeld CS et al. (2003): Estrogen receptor-a gene deficiency enhances androgen biosynthesis in the mouse Leydig cell. Endoccrinology, 144: 84-93.

30- Nakamura D, Yanagiba Y, Duan Z et al. (2010): Bisphenol A may cause testosterone reduction by adversely affecting both testis and pituitary systems similar to estradiol. Toxicol. Lett., 194: 16-25.

31- Gurmeet K S S, Rosnah I, Normadiah M Ket al. (2014): Detrimental effects of bisphenol a on development and functions of the male reproductive system in experimental rats. EXCLI. J., 13: 151-60.

32- Vandenberg LN, Maffini MV, Sonnenschein C et al (2009): Bisphenol-A and the Great Divide, AReview of Controversies in the Field of Endocrine Disruption. Endocr. Rev., 30:75-95.

33- Abdelzaher W Y, Ali DA, Khalil W K (2018): Could Licorice prevent Bisphenol A-Induced Biochemical,Histopathological and Genetic Effects in the Adult MaleAlbino Rats? Ain Shams Journal of Forensic Medicine and Clinical Toxicology, 30: 73-87.

34- Tamer S, Eizenberg M, Somjen D et al. (2017): Estrogen like activity of glabredene and other constituents isolated from licorice root. J Steroid Biochem. Mol. Biol., 74: 101104.

35- Helal E G, Zaki D A, Abdelaziz M A et al. (2019) : Effect of Both Bisphenol - A and Liquorice on Some Sexual Hormones in Male Albino Rats and Illustration of the Effect of Stem Cell Enhancer on Their Actions. The Egyptian Journal of Hospital Medicine, 77 (6): 5922-5929

36- Helal E G, El-Aleem M A, Ahmed SS (2019): Comparison between Sesame Oil and Glycyrrhizaglabra Effect as Phytoestrogen on Male Albino Rats. The Egyptian Journal of Hospital Medicine, 75 (4): 2550-2555

37- Biswas N M, Chaudhuri A, Sarkar M et al. (1996): Effect of ascorbic acid on in vitro synthesis of testosterone in rat testis. Indian Journal of Experimental Biology, 34 (6): 612-613.

38- Karanth S, Wen H Y, Walczewska A et al. (2001): Ascorbic acid stimulates gonadotropin release by autocrine action by means of NO. Proceedings of the National Academy of Sciences, 98 (20): 11783-11788. 